\title{
Presentation of the Results of the Survey on the Importance of Leadership Competences in the Logistics Industry
}

\author{
JACEK JAKUBOWSKI \\ Institute of Human Capital, Collegium of Business Administration, \\ SGH Warsaw School of Economics
}

\begin{abstract}
The aim of the article is to present the most important, according to logistics practitioners, leadership competences in logistics. The competences examined come from the Dynamic Leadership Model of SGH Warsaw School of Economics, developed by the Institute of Human Capital under the guidance of Professor Tomasz Rostkowski. The research was conducted from September to November 2018, using an online survey addressed to managers and executives in the logistics industry. The paper presents the most important competences in logistics according to the respondents: business orientation, building relations and cooperation, sharing experience, creating changes and decision making.
\end{abstract}

Keywords: logistics, supply chain, Leadership, SGH Dynamic Leadership Model JEL Classification Code: M12 


\section{Introduction}

The contemporary market consists of a large number of companies, similar goods, large sales opportunities and the informed consumer. The value that the consumption of goods brings to the consumer is increasingly important. The world of logistics must, therefore, provide this value. Value chain management outside of standard components such as storage or transport includes customer service, post-sales service and more. Thus, industry leaders should focus on value chain management. A leader in logistics should implement best market practices and develop his or her own solutions to improve efficiency. Having hard logistical skills is not enough. Managers should consider their entire organisation in a global context, have soft skills and learn to build relationships (Hofman, 2011; Caplice, 2011; Deloitte, 2014).

\section{Specificity of the logistics industry}

Supply chain management is a way of doing business efficiently (Beier \& Rutkowski, 1997). Modern business is based primarily on gaining a competitive advantage. Optimised logistics processes reduce the costs of the enterprise's operations - most of them are usually costs generated by logistics processes (Rutkowski, 2016). Because of the current tendency of organisations to compete using the entire supply chains, the competences of logistics leaders become particularly important.

Recent years have brought growing consumption and investment in Poland. This translates into increased demand for supply chain management services. Companies started to face difficulties in obtaining qualified employees and employment costs increased (Fechner, Szyszka, 2018).

The share of logistics in Poland's GDP is growing, in 2017 it amounted to about $11.5 \%$. Logistics is not just about transport or storage companies. Supply chain management is one of the functional strategies of every company (Fechner \& Szyszka, 2018).

There is no one proper style of leadership in logistics that determines success, because this industry is characterised by constant change. Leaders should constantly seek innovation and implement change to remain competitive in the market. They are expected to demonstrate vision, ability to manage people, build relationships, gather information, and make decisions (APICS Supply Chain, 2015). 


\section{Associates of the leader}

People responsible for managing the supply chain are very diverse. A logistics leader's associates will include a warehouse keeper, a forklift operator, a planner, as well as a transport specialist, a warehouse manager, a driver or an IT specialist. The form of business and outsourcing policy are also important. When using services of a logistics operator one partially replaces human capital management with building relationships with the operator. The above is an evidence of the great diversity of positions in supply chain management, as well as a wide range of hierarchies within the organisation. Supply chain employees can be divided into operational employees in the strict sense, such as warehouse workers, drivers, forklift operators and office staff. The last few years have been good for employees in logistics. They can easily change jobs and are well paid (LBQ, 2017; Górny, 2018; Jaszcz, 2018).

In the 'employee market', employees are more demanding and employers need to motivate them not only financially. In the logistics industry there are some barriers to an employee entering the market. In the operational part, in the strict sense, these are, among others, driving licences. For office work, on the other hand, it is mainly the ability to handle specialised logistics programmes, such as SAP software. At a time of workforce shortage companies decide to sponsor courses that end up with employees obtaining appropriate qualifications in exchange for a loyalty agreement, and they also decide to train on their own in handling the necessary programmes.

Summarising the above, it can be said that the specificity of followership in the logistics industry is primarily determined by the following issues:

- Cooperation of employees at all levels of the organisational hierarchy;

- Situation on the labour market - "employee market";

- Very high demand for logistics services on the market;

- In addition, there is also a shortage of employees on the labour market, which is also experienced by other industries.

It is worth mentioning that due to the above specificity of followership, it is necessary to focus on the leadership competences of logistics industry leaders, because it is their task to build teams effectively for supply chain management. 


\section{Key stakeholders}

\section{Clients}

The final stage of any supply chain management process is to receive payment for the delivery of goods to the final customer or even to the consumer. Thanks to a properly designed supply chain, it is possible, among others, to shorten order-todelivery and order-to-cash times, increase the availability of products, as well as streamline ordering process. It has a direct impact on the benefits offered to the customer from purchasing the product. Customers will strive to maximise these benefits from purchasing the product.

\section{Internal clients of the organisation}

The supply chain affects all departments of the organisation, not only sales and marketing, which will certainly be crucial for the organisation's operations, but also finances. This means that it is necessary to combine the expectations of fast and high product availability with the maximum reduction of the cash-to-order period.

\section{Stakeholders in connection with formal and legal aspects}

Logistics is subject to many legal regulations. Inspection bodies are also stakeholders in the logistics industry. They will supervise the organisation's activities, expect explanations and data on the company's activities. Due to the high responsibility of logistics departments in organisations, conducting activities in an orderly manner is crucial so that these stakeholders can as efficiently as possible carry out their inspections. Any stoppage or slowdown of logistics processes generates costs that are difficult to minimise later on.

\section{Society}

Transport, marketing of packaging, warehouses, factories have an impact on the environment and people through external effects. Logistics departments must also focus on CSR activities - use, e.g., cars with combustion standards or collective packaging made of biodegradable materials, manage returnable packaging, organise 
disposal of unsold products. Society is increasingly interested in environmental protection and expects this from businesses. Also new regulations in Poland and in the European Union concerning environmental protection continue to emerge.

\section{Trends in the industry}

For several years, supply chains in organisations have been subject to optimisation. Their proper management is crucial in the current market dynamics. Any goods present at any stage of the chain represent frozen working capital, and the costs generated by logistics constitute the largest part of production and trade costs. The supply chain industry is constantly seeking further improvements. These include, among others:

- Internet of things, i.e., a network of connections between different devices, machines.

- SMAC, a set of four cooperating technologies: Social Media, Mobile Technologies, Analytics (Big Data), Cloud Computing.

- 3D printing, some parts are already produced on 3D printers, which greatly reduces the cost of production and product flow within the supply chain from raw materials to semi-finished or finished products.

- Robotisation and automation - in the face of the shortage of employees and rising employment costs, companies are gradually inventing new ways to reduce employment by automating their logistics.

- Autonomous vehicles - transport is an integral part of the supply chain. Elimination of the human factor in this part is associated with great savings, but also with increased efficiency.

- Virtual reality - augmented reality can be used to support human activities. It can provide, among other things, additional information for employees to complete orders in an accessible way (Rutkowski, 2016).

- Information and communication technologies - logistics is not possible without information flow. The desire for easy access to information forces the use of mobile technologies and increased efficiency of information flow through the development of information technologies (Ocicka, 2017).

In the coming years there will be another major development of supply chain management technology. Among other things, one indicates the use of artificial intelligence, integration of large amounts of data, robotisation, automation, mobile technologies (IDC Future Scape, 2018).

The expected development in the logistics industry will certainly require leaders who can manage this development and who will implement new solutions 
and technologies. Therefore, attention should also be paid to the most important leadership competences in logistics.

\section{Leadership in logistics and supply chain in the light of the ongoing research}

\section{Introduction to the study}

Organisations undeniably need good and strong leaders in logistics. Many publications point to particular characteristics that help these leaders, but do not provide a complete base of leadership competences. Therefore, an attempt has been made to clearly define leadership competences of particular importance in the supply chain management and logistics sector. A survey was conducted in which logistics leaders indicated the most important and least important leadership competences and evaluated themselves through the prism of these competences. The competences included in the survey were derived from the Dynamic Leadership Model of the Institute of Human Capital at SGH Warsaw School of Economics.

\section{Construction of the survey}

The survey was prepared with the help of an online tool. The study was divided into seven sections. The first one included an explanation of the purpose of the survey as well as a question categorising the respondents in the form of a request to determine the organisation's activities from among five options:

- Manufacturer/Service provider with its own logistics (in full or mostly);

- Manufacturer/Service provider with outsourced logistics (in full or mostly);

- Logistics operator;

- Distributor;

- Wholesaler.

The next four sections of the survey included the main survey questions in which the most relevant, least relevant, best developed and least developed leadership competence in each competence area should be selected.

After the main questions of the survey, two questions were asked about the existence of competence profiles in the organisation. They checked the inclusion of leadership competences in the organisation's competence profiles and the inclusion of the leadership competences presented in the survey. There were four possible answers: 'yes', 'no', 'I don't know', 'I don't want to answer'. 
The last screen of the survey is the part devoted to the statistical data about the respondents: gender, age and positions held (President/Owner, Director, Manager, Executive).

Thanks to such a selection of questions in the survey, it was possible not only to identify the most important, according to the management, leadership competences in logistics, but also to check for the existence of a possible impact of the form of activities conducted by the organisation and the respondent's position on the results of the survey.

\section{Results and conclusions of the study}

Table 1. Activity profiles of the organisation

\begin{tabular}{|l|c|c|}
\hline \multicolumn{1}{|c|}{ Activity profile of the organisation } & $\begin{array}{c}\text { Number of } \\
\text { respondents }\end{array}$ & $\begin{array}{c}\text { Percentage of } \\
\text { respondents }\end{array}$ \\
\hline $\begin{array}{l}\text { Manufacturer/Service provider with its own logistics } \\
\text { (in full or mostly) }\end{array}$ & 28 & $41 \%$ \\
\hline $\begin{array}{l}\text { Manufacturer/Service provider with outsourced logistics } \\
\text { (in full or mostly) }\end{array}$ & 14 & $20 \%$ \\
\hline Logistics operator & 13 & $19 \%$ \\
\hline Distributor & 10 & $14 \%$ \\
\hline Wholesaler & 4 & $6 \%$ \\
\hline Total & 69 & $100 \%$ \\
\hline
\end{tabular}

Source: own study based on research results.

Table 2. Positions of the respondents

\begin{tabular}{|l|c|c|}
\hline \multicolumn{1}{|c|}{ Position } & Number of respondents & Percentage of respondents \\
\hline Manager & 40 & $58 \%$ \\
\hline Executive & 13 & $19 \%$ \\
\hline Director & 11 & $16 \%$ \\
\hline President/owner & 5 & $7 \%$ \\
\hline Total & 69 & $100 \%$ \\
\hline
\end{tabular}

Source: own study based on research results. 


\section{Figure 1. Age distribution of the respondents}

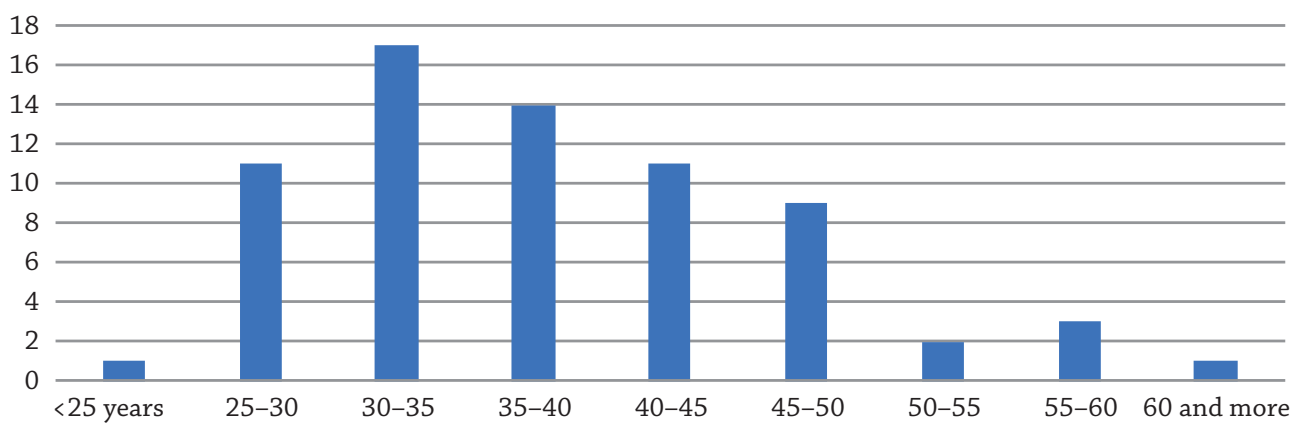

Source: own study based on research results.

Table 3. Gender of the respondents

\begin{tabular}{|l|c|c|}
\hline \multicolumn{1}{|c|}{ Gender } & Number of respondents & Percentage of respondents \\
\hline Women & 16 & $23 \%$ \\
\hline Men & 53 & $77 \%$ \\
\hline Total & 69 & $100 \%$ \\
\hline
\end{tabular}

Source: own study based on research results.

Figure 2. Distribution of the respondents' positions grouped into profiles of the organisation's activities

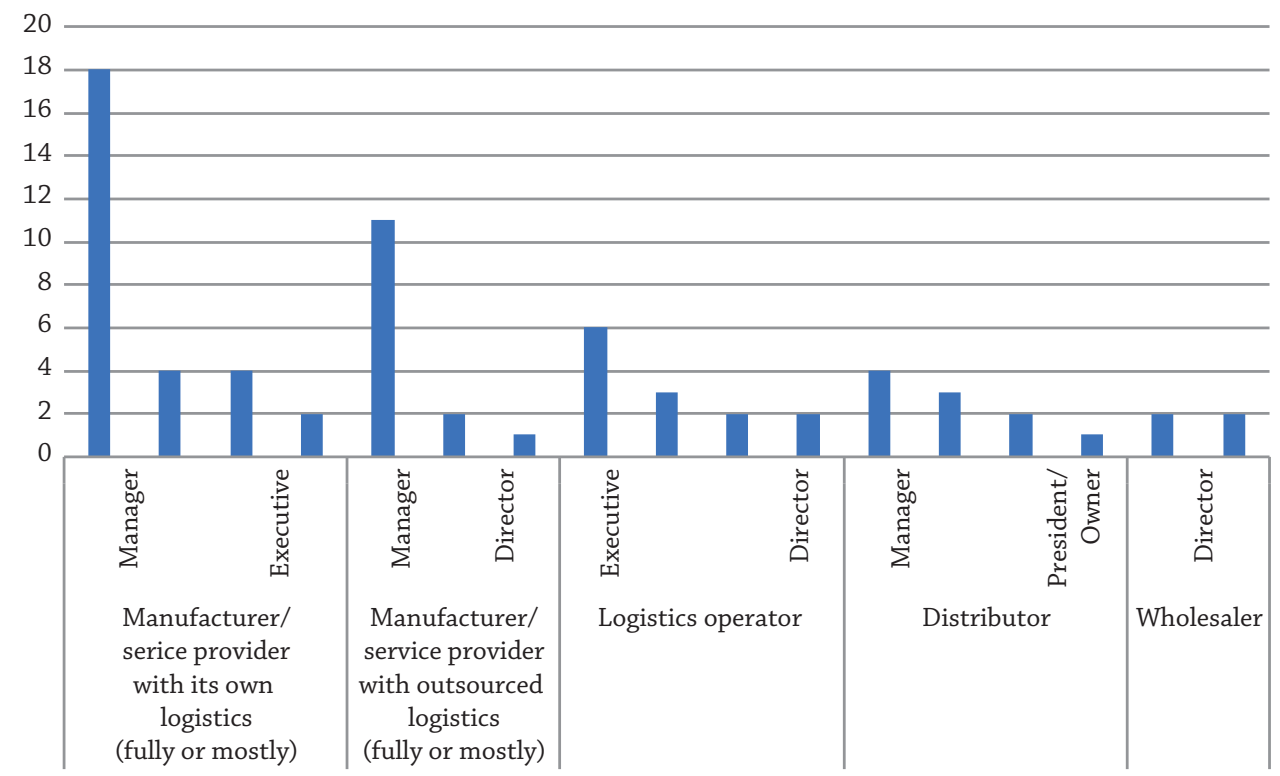

Source: own study based on research results. 
There was no significant impact of the organisation's activity profiles and the positions of the respondents on questions concerning the importance of competences and subjective assessments of competence development. However, due to the corresponding characteristics, it is possible that the results of the survey will be most applicable to managers working at manufacturers/service providers with their own logistics. The age and gender of the respondents also did not influence the results of the research.

\section{Creating vision - study results}

Figure 3. Key competences in the area of Vision creation

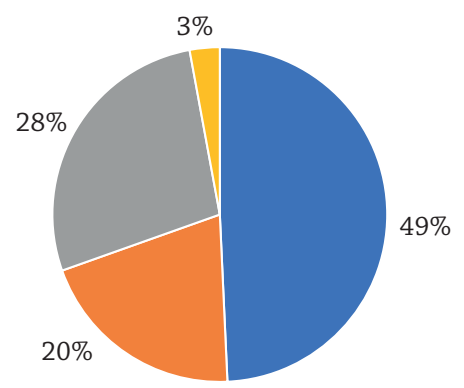

- Business orientation

- Implementing long-term plans

Implementing vision and values

$\square$ Managing short-term objectives

Source: own study based on research results.
Figure 4. Least important competences in the area of Vision creation

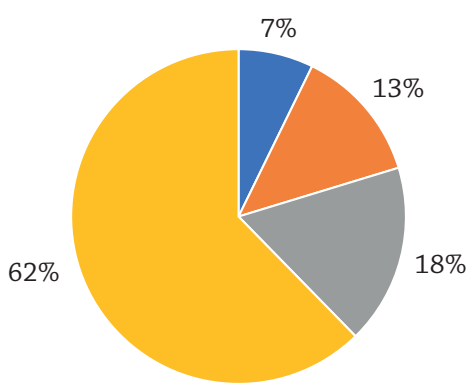

- Business orientation

- Implementing long-term plans

Implementing vision and values

Managing short-term objectives

Source: own study based on research results.

Undoubtedly, business orientation is very important in logistics. This is probably the response of managerial staff in this industry to market expectations and the transition from standard supply chain management to value chain management. Today's customer no longer wants only goods or services, but also the greatest possible benefits from the offer.

The management of short-term objectives was indicated as the least important competence and most people assessed it as the least developed one. This may be due to the specificity of management and the fact that working with short-term objectives is considered particularly important at operational levels which are lower in the organisational hierarchy. 
Figure 5. Best developed competences in the area of Vision creation

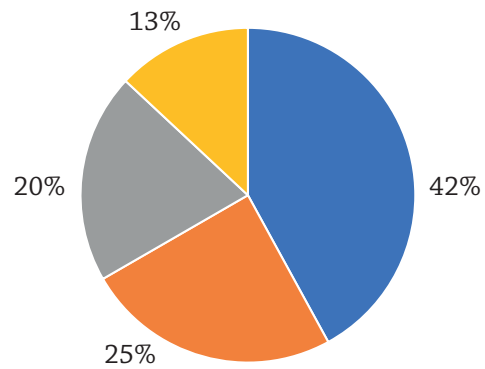

- Business orientation

Implementing vision and values

Implementing long-term plans

Managing short-term objectives

Source: own study based on research results.

\section{Figure 6. Least developed competences in the area of Vision creation}

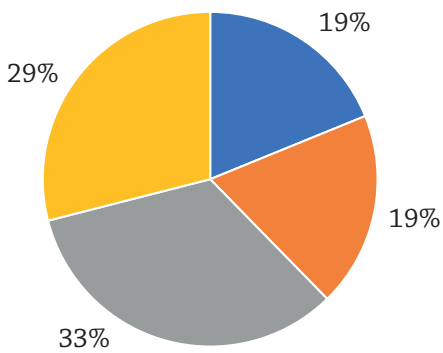

- Business orientation

- Implementing long-term plans

- Implementing vision and values

Managing short-term objectives

Source: own study based on research results.

\section{Shaping commitment - study results}

Figure 7. Key competences in the area of Shaping commitment

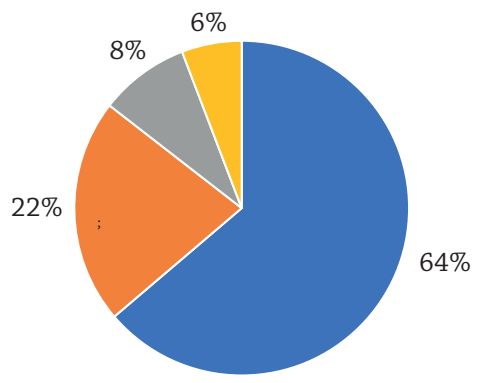

- Building relationships and cooperation

Inspirational influence

- Trust building

Individual treatment

Source: own study based on research results.
Figure 8. Least important competences in the area of Shaping commitment

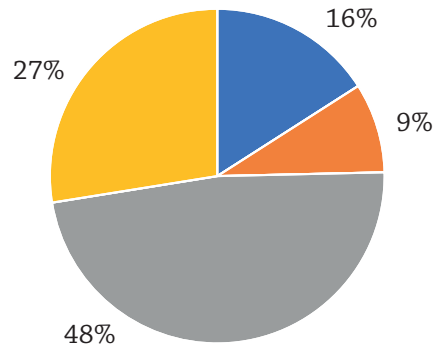

- Building relationships and cooperation

- Trust building

- Individual treatment

Inspirational influence

Source: own study based on research results.

The specificity of the supply chain management industry is based on cooperating with all departments of the organisation. This is confirmed by the indication of the competence of building relationships and cooperation as being by far the most important. According to the respondents, this is definitely more important than 
having an impact or individual approach. Executive and managerial positions of the respondents may result from the fact that they are aware of the relationship feature required by the nature of logistics. Probably they are part of the managerial body thanks to a well-developed abilities of building relationships and cooperation.

Figure 9. Best developed competences in the area of Shaping commitment

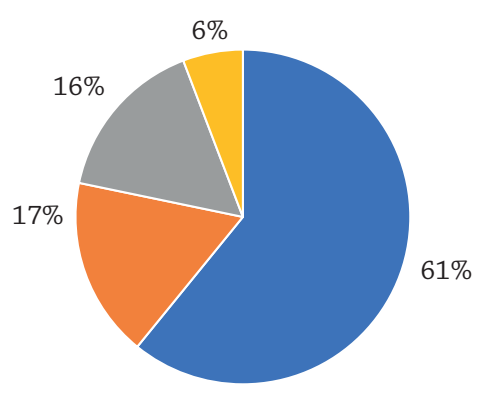

- Building relationships and cooperation

- Inspirational influence

- Trust building

Individual treatment

Source: own study based on research results.
Figure 10. Least developed competencies in the area of Shaping commitment

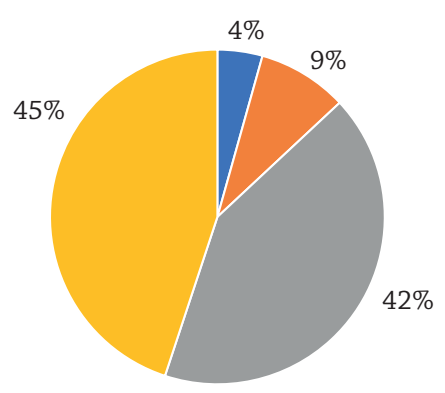

- Building relationships and cooperation - Trust building

- Individual treatment

Inspirational influence

Source: own study based on research results.

\section{Supporting development - study results}

The recognition of mentoring as well as the creation of conditions for development as the most important competences show that taking care for employee development is very important in logistics. Due to the currently high and constantly growing expectations towards logistics departments, high competences of employees are also necessary, which the management is aware of (indicating lesser importance of own development). 
Figure 11. Key competences in the area of Supporting development

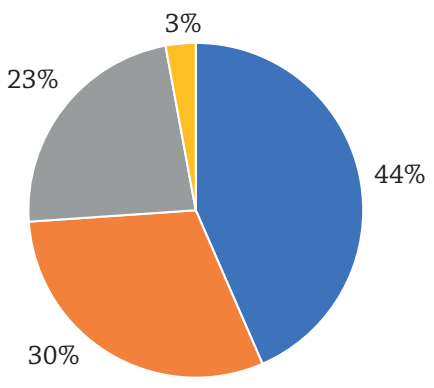

Mentoring - sharing experience

Creating conditions for development

- Recognition of competence potential

$\square$ Taking care of your own development

Source: own study based on research results.

Figure 13. Best developed competences in the area of Supporting development

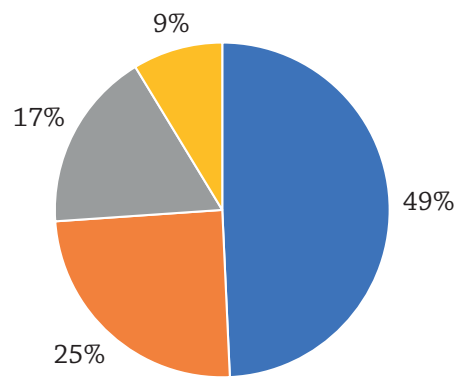

- Mentoring - sharing experience

- Creating conditions for development

- Recognition of competence potential

Taking care of your own development

Source: own study based on research results.
Figure 12. Least relevant competences in the area of Supporting development

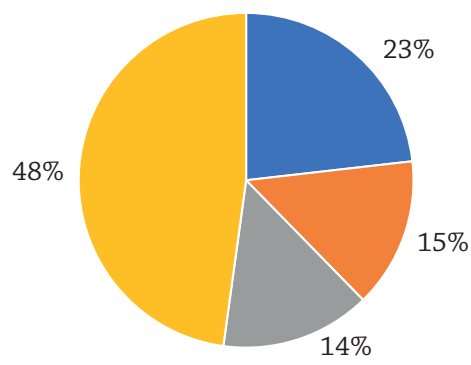

Mentoring - sharing experience - Creating conditions for development - Recognition of competence potential

Taking care of your own development

Source: own study based on research results.

Figure 14. Least developed competences in the area of Supporting development

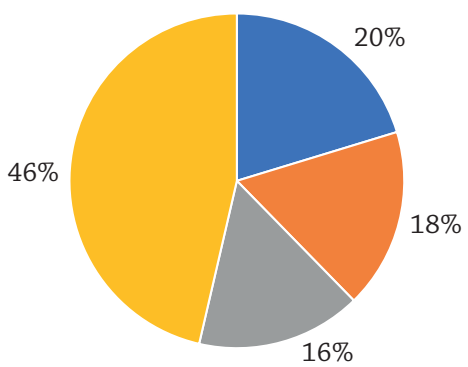

- Mentoring - sharing experience - Creating conditions for development - Recognition of competence potential

Taking care of your own development

Source: own study based on research results. 


\section{Creation of changes - study results}

Figure 15. Key competences in the area of Creation of changes

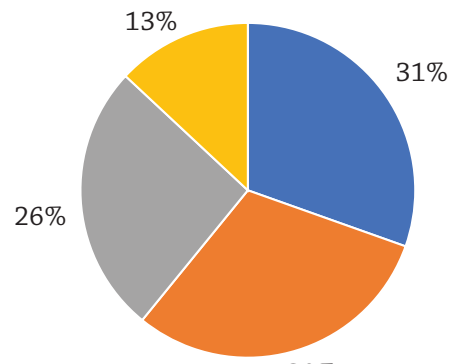

$30 \%$

Anticipating the problem

- Proactivity

- Pro-innovativeness

- Taking a conscious risk

Source: own study based on research results.

Figure 17. Best developed competences in the area of Creation of changes

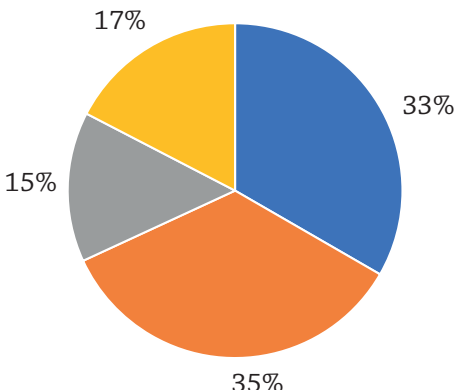

Anticipating the problem

- Proactivity

- Pro-innovativeness

Taking a conscious risk

Source: own study based on research results.
Figure 16. Least important competences in the area of Creation of changes

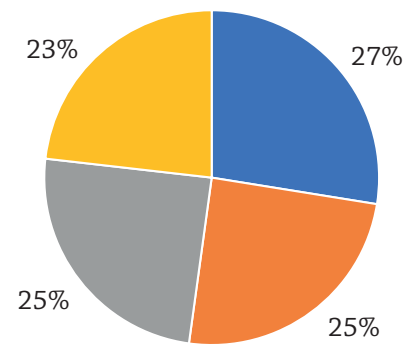

Anticipating the problem

Proactivity

- Pro-innovativeness

- Taking a conscious risk

Source: own study based on research results.

Figure 18. Least developed competences in the area of Creation of changes

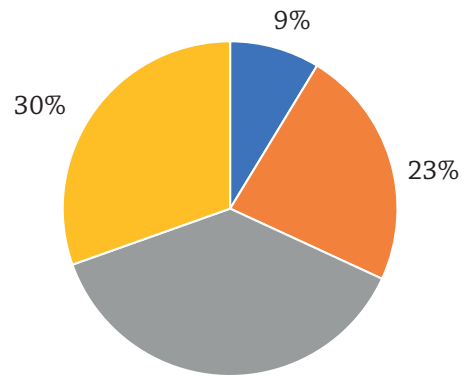

$38 \%$

- Anticipating the problem

- Proactivity

Pro-innovativeness

Taking a conscious risk

Source: own study based on research results.

Answers reveal that taking a conscious risk is the least important competence in logistics. It may be because logistics is not exactly where the risk is needed. Logistics 
is supposed to work effectively, and all its activities should not be burdened with a high level of risk. At the same time, the study shows proactivity as an important feature. Organisations cannot function without effective supply chain management, hence the high importance of this competence in the managers' opinion. The studied managerial staff has highly developed competences of anticipating problems and proactivity. In addition, many respondents have identified this competence as the most important. This is certainly due to the characteristics of the logistics industry and the need to solve many problems that arise during dynamic situations. Research results in this area suggest that it is difficult to identify one most important competence. This is probably connected to the fact of a continuous strive for improvement of logistics processes in various ways.

Accompanying competences - study results

Figure 19. Key competences in the area of Accompanying competences

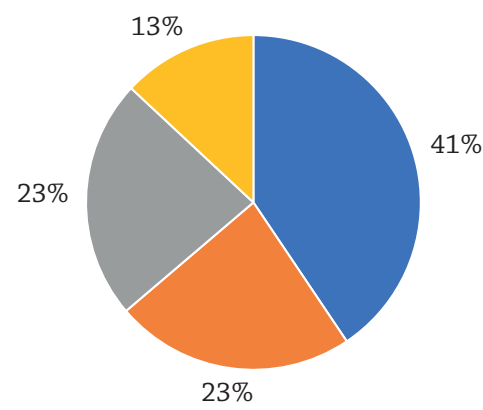

- Decision making

- Leadership communication

- Flexibility

- Authority

Source: own study based on research results.
Figure 20. Least relevant competences in the area of Accompanying competences

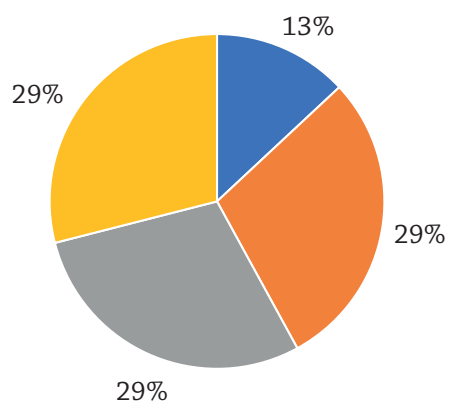

Decision making

- Leadership communication

- Flexibility

Authority

Source: own study based on research results.

The respondents indicated the decisiveness competence as the most important and best developed in them. This is certainly influenced by the need to make many quick decisions in a dynamic environment. 
Figure 21. Best developed leadership competencies in the area of Accompanying competences

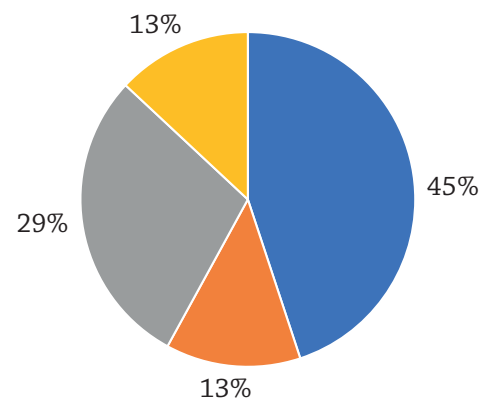

Decision making

- Leadership communication

Flexibility

Authority

Source: own study based on research results.

\section{Figure 22. Least developed competences in the area of Accompanying competences}

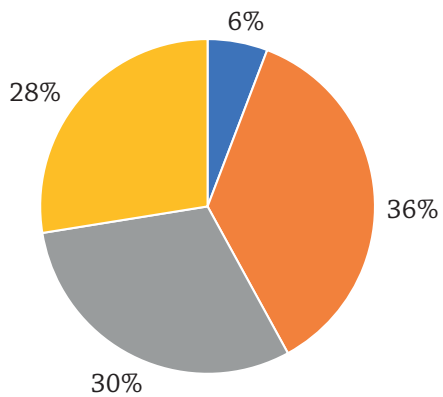

- Decision making

- Leadership communication

Flexibility

Authority

Source: own study based on research results.

\section{Competence profile in organisations - study results}

Figure 23. The existence of a competence Figure 24. The existence of a competence profile, taking into account any leadership competences

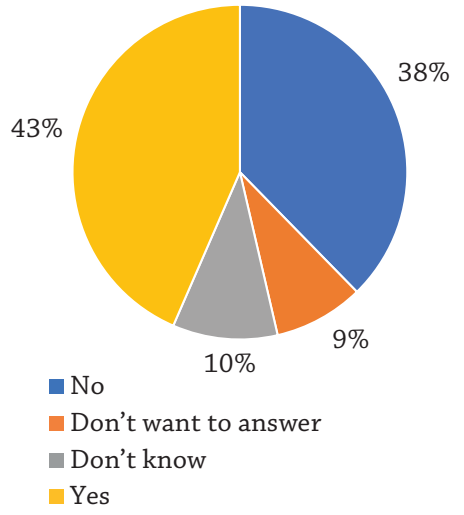

Source: own study based on research results. profile, taking into account the leadership competences of the model

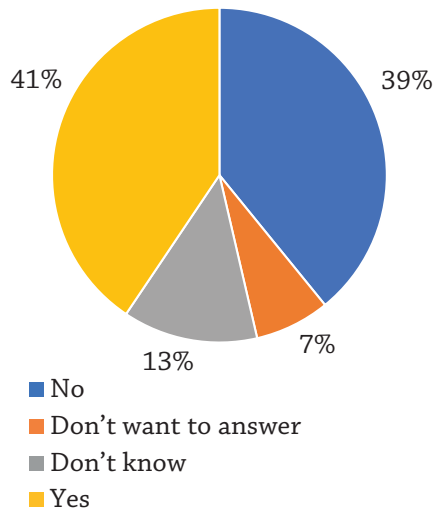

Source: own study based on research results.

Leadership competences appear in the competence profiles of the organisation. The presence of the answers 'I don't know' and 'I don't want to answer' could 
mean that the respondents are not fully aware of the existence of profiles in their organisations or that they are not familiar with them.

\section{Conclusion}

Organisations constantly strive to improve the efficiency of their supply chain management. This is a way for them to develop their business. Hence, the need for the leaders in this industry. Logistics operates in the conditions of constant change, so there is no one proper leadership style. Thanks to the study, it can be clearly stated that logistics requires from leaders to be business-oriented, to build relationships and cooperate well, to share experiences and to focus strongly on creating change. All this should be supported by decisiveness. At the same time, leaders in logistics should pay special attention to the correct construction of competence profiles. This can make the process of recruitment and selection of candidates for positions in their organisations easier and facilitate identifying areas for development among current employees, which will definitely contribute to increased effectiveness of teams.

The survey shows that leadership in logistics is particularly important. The presented model of Dynamic Leadership of SGH Warsaw School of Economics proves itself in the supply chain management and logistics sector. On the other hand, it is worth noting that there is a gap in the study of leadership competences in logistics, and it would be worthwhile to conduct further research to provide high-quality methods for the development and certification of key leadership competences in the industry.

\section{References}

APICS Supply Chain (2015). Supply chain leadership report: Many styles generate success. Retrieved from: http://www.apics.org/docs/default-source/scc-non-research/supplychain-leadership-report---many-styles-generate-success---apics-scc.pdf?sfvrsn=2 (accessed: 20.10.2020).

Beier, F., \& Rutkowski, K. (1997). Logistyka. Warsaw: SGH Warsaw School of Economics. Caplice, C. (2011, March-April). Three questions that define the leadership debate. Supply Chain Management Review, 10-11.

Deloitte (2014). Supply chain leadership. Retreived from: https://www2.deloitte.com/ content/dam/Deloitte/at/Documents/strategy/supplychain-leadership-report.pdf (accessed: 20.10.2020).

Fechner, I., \& Szyszka, G. (Eds.) (2018). Logistyka w Polsce, Raport 2017. Poznan: Institute of Logistics and Warehousing. Retrieved from: https://depot.ceon.pl/bitstream/ handle/123456789/15762/R17.pdf?sequence=1\&isAllowed=y (accessed: 20.10.2020). 
Górny, B. (2018). The lack of employees is affecting most logistics companies. Retrieved from: http://www.portalspozywczy.pl/technologie/wiadomosci/brak-pracownikowdoskwiera-wiekszosci-firm-logistycznych,156120.html (accessed: 20.10.2020).

Hofman, D. (2011, September-October). The top 25 supply chains: Leadership in action. Supply Chain Management Review, 8-15.

IDC Future Scape (2018). Worldwide supply chain 2019 predictions.

Jaszcz, Ł. (2018). Summary of the remuneration in logistics report in 2017. Retrieved from: https://wynagrodzenia.pl/artykul/podsumowanie-raportu-wynagrodzenia-wlogistyce-w-2017-roku (accessed: 20.10.2020).

LBQ (2017). The way to reduce the shortage of personnel in the logistics industry, i.e. how to recruit a valuable employee in three steps. Law Business Quality, April 3. Retrieved from: http://magazynlbq.pl/sposob-na-deficyt-kadry-w-branzylogistycznej-czyli-jak-zrekrutowac-wartosciowego-pracownika-w-trzech-krokach/ (accessed: 20.10.2020).

Ocicka, B. (Ed.) (2017). Technologie mobilne w logistyce i zarządzaniu łańcuchem dostaw. Warsaw: Polish Scientific Publisher.

Rutkowski, K. (Ed.) (2016). Zarządzanie łańcuchem dostaw w XXI wieku. Warsaw: SGH Publishing House.

\section{Jacek Jakubowski}

Graduate of second-degree studies in management and first-degree studies in Finance and Accounting at SGH Warsaw School of Economics. Particularly interested in the improvement of logistics processes and digitisation. He works in the logistics department and is additionally involved in helping in the activities of the Institute of Human Capital at SGH.

e-mail: jck.jakubowski@gmail.com

ORCID: 0000-0002-5731-6415 


\section{Typesetting and layout}

DM Quadro

\section{Printing and binding}

QUICK-DRUK s.c. tel. 426395292

e-mail: quick@druk.pdi.pl

Order 142/XII/20

\section{INFORMATION FOR THE AUTHORS}

\section{General information}

1. The editors of the Quarterly accept scientific articles and research reports (up to 15 pages of standardised computer printer/typewritten/text including references) as well as book reviews, information of conferences, symposiums, scientific seminars (up to 6 pages long).

2. Papers shall concern issues within the field of management and widely understood professional development. They should meet requirements of top scientific standards: high subject-of-the matter level, relevant and up-to-date problem area, application possibility, originality and contribution in the hitherto accomplishments in the specific field, language accuracy.

3. The article should follow the following layout: title, name and surname, and the author's affiliation, abstract (summary) of the article (up to 900 characters with spaces) key words (5-7), the full text of the article, references, information about the author (up to 900 characters with spaces).

4. The article should identify the following parts and elements: introduction with a clearly stated objective, the main part including the theoretical or empirical problem presentation, final conclusions.

5. The standard of text preparation:

- Times New Roman 12, space between lines 1.5, margins $2.5 \mathrm{~cm}$,

- bibliography footnotes at the bottom of the page arranged as follows,

- bibliographic references within the text (the Harvard style) in the following order: name of the author, year of publication,

- drawings and tables within the text, entitled, provided with sources,

- references at the end of the article, in the alphabetical order: name of the author, first letter of the author's first name, year of publication, title of the book/article, place of publication, publisher.

\section{Example:}

Armstrong, A. (2005). Zarządzanie zasobami ludzkimi. Kraków: Oficyna Ekonomiczna. Organ, D.W., Podsakoff, P.M., \& MacKenzie S.B. (2006). Organizational Citizenship Behavior: Its Nature, Antecedents, and Consequences. Thousand Oaks, CA: Sage. Juchnowicz, M. (2014). Istota i struktura kapitału ludzkiego. In: M. Juchnowicz (Ed.), Zarzq̨dzanie kapitałem ludzkim. Procesy, narzędzia, aplikacje, Warszawa: PWE, 29-37. Anderson, N., \& Gasteiger, R.M. (2008). Helping Creativity and Innovation Thrive in Organizations: Functional and Dysfunctional Perspectives. In: J. Langan-Fox, 
C.L. Cooper, R.J. Klimoski (Eds.), Research companion to the dysfunctional workplace Cheltenham, UK: Edward Elgar Publishing, Inc., 422-440.

Zhang, Y., Lepine, J., Buckman, B.R., \& Wei, F. (2014). It's Not Fair... or Is It? The Role of Justice and Leadership in Explaining Work Stressor-job Performance Relationship. Academy of Management Journal, 57(3), 675-697.

6. The text can be e-mailed to the editorial office: ikl@sgh.waw.pl. The article paper version shall be posted to the address of the editorial office.

7. Meeting the requirements concerning the right preparation of the text andreceiving a positive opinion of reviewers is a prerequisite to acceptance of the text.

8. In order to prevent the phenomena of 'ghostwriting', 'guest authorship' and to ensure scientific diligence, the author shall be obliged to reveal their own and co-authors' contribution in the publication (providing their affiliation and involvement, i.e. information on who the authors of the concept are, assumptions, methods, etc. used while preparing the publication) with the major responsibility being borne by the author submitting the article for publication. Any detected cases of a lack of due diligence and dishonesty will be revealed, followed by informing appropriate entities.

9. The Journal adheres to the Core Practices of the Committee on Publication Ethics (COPE, https://publicationethics.org/core-practices) and follows their guidelines in respect of publication ethics and managing problems when they arise.

\section{The Quarterly's reviewing procedure and rules}

1. Positive reviews of two independent reviewers are the prerequisite to the publication of the article.

2. Reviewers are appointed from among those being outside the scientific unit publishing the Quarterly.

3. Double-blind review process is obligatory.

4. A review is made in writing, by filling in a suitable form including the substantive and formal assessment criteria. A reviewer presents the justification of the article assessment as well as suggestions of changes of both the subject-of-the-matter and editorial nature.

5. A reviewer presents the final recommendation - a decision concerning the rejection on the article, the necessity for the article to be reviewed again (following necessary changes to the article or accepting the article to be printed).

\section{List of regular reviewers}

Prof. Piotr Błędowski, PhD (SGH Warsaw School of Economics, Warsaw, Poland)

Prof. Christina Ciecierski, PhD (Northeastern Illinois University, Chicago, USA)

Prof. Zdzisława Janowska, PhD (University of Business and Administration in Gdynia, University of Lodz, Poland)

Prof. Hanna Karaszewska, PhD (UTP University of Science and Technology in Bydgoszcz, Bydgoszcz, Poland)

Prof. Alicja Miś, PhD (Cracow University of Economics, Cracow, Poland)

Prof. Renata Oczkowska, PhD (Cracow University of Economics, Cracow, Poland)

Prof. Tadeusz Oleksyn, PhD (University of Finance and Management, Warsaw, Poland)

Prof. Józef Orczyk, PhD (Poznań University of Economics and Business, Poznan, Poland)

Prof. Roman Sobiecki, PhD (SGH Warsaw School of Economics, Warsaw, Poland) 